\title{
Fantastic Voyage: Influenza
}

Julian W. Tang

Time to go! Time to go!

An influenza virus,

Hiding in saliva, buried in a cell,

Antibodies and T-cells are coming.

Get out! But how?

Induce a sneeze? Kick-start a cough?

Ah yes, here we go ...

Aahhh-choo! Freedom at last!

Where are we?

A quick look around

A hospital? I see children,

Very thin, sick children,

Must be the cancer ward.

No B cells or T cells - a virus paradise!

Let's travel, find a breeze and float.

Where's my next victim?

My previous young doctor host

Walking quickly away

Head down, embarrassed

Scolded by a nurse - where was his mask?

Too busy and careless, poor fool

He still serves me well, dragging me into his wake.

Here I go, following and floating

A door nearby opens-negative pressure!
In I go, but on a cancer ward,

This should be positive pressure!

To keep bugs out, not draw them in.

I cannot complain

All good for me, for now I can see

A young girl with leukemia

Sitting in bed, watching TV

Laughing, inhaling, bringing me close.

But wait, what's this? Her mother!

Opening the toilet door,

Even greater negative pressure in there.

And worse, wet surfaces glistening inside,

Cleaned by her mother with chlorhexidine.

No! Not yet! Not now! I'm so close!

Being pulled in. No escape. Falling, falling ...

The young girl is laughing. Now her mother is too.

Dr Tang is a clinical and academic virologist with a special interest in aerosol-transmitted viral infections, particularly influenza. His research interests include viral molecular epidemiology and investigations into the factors involved in the aerosol transmission of viral infections.

Address for correspondence: Julian W. Tang, Division of Microbiology/ Molecular Diagnostic Centre, Department of Laboratory Medicine, National University Hospital, 5 Lower Kent Ridge Rd, Singapore 119074; email: jwtang49@hotmail.com

Author affiliation: National University Hospital, Singapore

DOI: 10.3201/eid1503.080669 